\title{
Regional economic structure and heterogeneous effects of monetary policy: evidence from Indonesian provinces
}

\author{
Harry Aginta ${ }^{1 *}$ and Masakazu Someya ${ }^{2}$
}

*Correspondence:
harry_ag@bi.go.id
${ }^{1}$ Bank Indonesia
and Graduate School
of International
Development, Nagoya
University, Nagoya, Japan
Full list of author information
is available at the end of the
article

\begin{abstract}
We analyze how regional economic structures affect the impact of monetary policy on rates of inflation across 34 Indonesian provinces. The paper first applies structural factor augmented vector autoregressive model (SFAVAR) to all the 34 provinces based on monthly provincial data in order to measure the length and magnitude of responses of regional inflation to monetary policy shock, derived from the consequential impulse response functions of 34 provinces. In the second step, we analyze the impact of economic structures on the length and magnitude of regional inflationary responses of 34 provinces. We find that the impacts of monetary policy across regions are significantly influenced by economic structural variables such as manufacturing sector share to GDP, mining sector share to GDP, bank lending share to GDP and export share to GDP. In addition, we found the spatial lag, rate of inflation of neighboring provinces, is also statistically significant. In a similar fashion, economic structural variables such as manufacturing sector share to GDP, construction sector share to GDP and investment share to GDP are found statistically significant in explaining regional differences of monetary policy efficiency. Our findings imply economic structures of provinces have to be incorporated to designing monetary policy in Indonesia.
\end{abstract}

Keywords: Monetary policy transmission, Economic structure, Inflation, Indonesia, E52, R11

JEL Classification: E52, R11

\section{Background}

Generally, the effects of monetary policy actions are evaluated at the national level. In reality, no aggregate economic shocks, including those from monetary policy actions, affect only national aggregates; they also impact regional economic activities. Since most nations are composed of diverse regions, the effects of aggregate economic shocks are not necessarily uniform across regions (Carlino and DeFina 1998). More importantly, a body of literature suggests that monetary policy rules that ignore information at the regional level may lead to welfare losses when there are asymmetries in the transmission mechanism (De Grauwe 2000; Gros and Hefeker 2002); in other words, such monetary policy might not be optimal.

(c) The Author(s) 2022. Open Access This article is licensed under a Creative Commons Attribution 4.0 International License, which permits use, sharing, adaptation, distribution and reproduction in any medium or format, as long as you give appropriate credit to the original author(s) and the source, provide a link to the Creative Commons licence, and indicate if changes were made. The images or other third party material in this article are included in the article's Creative Commons licence, unless indicated otherwise in a credit line to the material. If material is not included in the article's Creative Commons licence and your intended use is not permitted by statutory regulation or exceeds the permitted use, you will need to obtain permission directly from the copyright holder. To view a copy of this licence, visit http:// creativecommons.org/licenses/by/4.0/. 
Optimal monetary policy is theoretically derived from the maximization problem of a representative agent's welfare function. In practice, monetary policy targets the national consumer price index (CPI) inflation, that is, the growth rate of the cost of living for the "average" consumer. Indeed, empirical findings show evidence that supports the possibility that people in different parts of a country face some heterogeneity in price behavior. For instance, Cecchetti et al. (2002) use annual city-level data for 1918-1995 and find price divergences among 19 cities in the United States, attributed to transportation costs and differences in the speed of adjustment to supply shocks. Some studies also provide evidence on heterogeneous regional price behavior in Indonesia. Using CPI data across 82 cities in Indonesia, Jangam and Akram (2019) and Aginta (2020a) find that regional prices do not converge to a common path. They show that instead, city prices evolve in four convergence clubs. Similarly, Aginta (2020b) uses CPI data of the 34 Indonesian provinces and finds four convergence clubs of price dynamics across provinces. Such heterogeneity in regional price behaviors might lead to different responses to a common national policy shock and has potentially significant consequences for the implementation of monetary policy in Indonesia.

Despite the evidence of regional price heterogeneity in Indonesia, little is known about the effects of monetary policy on regional inflation. To the best of our knowledge, only the study of Ridhwan et al. (2014) attempts to analyze the regional impacts of Indonesia's monetary policy. They find two crucial regional features that significantly determine the regional effects of monetary policy: industrial structure (especially the share of the manufacturing industry) and firm and bank size. In the context of the Indonesian economy, these findings imply the significance of the interest rate and credit channels of monetary policy transmission. However, their study focuses on exploring the sources of variation in monetary policy impacts on regional output. In addition, their observations cover only 26 Indonesian provinces, and they apply a standard VAR model.

Against this backdrop, our paper contributes to the existing literature in at least three ways. First, we scrutinize regional asymmetries of monetary policy transmission and the impact on regional inflation and evaluate the role of regional structural characteristics in these asymmetries. Our focus on analyzing regional inflation is consistent with the mandate of Indonesia's central bank to maintain rupiah stability, reflected in inflation. ${ }^{1}$ Given this mandate, it is crucial for the central bank to understand how the regional economic structure affects monetary policy transmission to the inflation rate in the entire archipelago. Second, we combine a standard structural vector autoregression (VAR) model with factor analysis into a factor-augmented VAR (FAVAR) to exploit a more extensive dataset. Unlike general VAR models, which might not capture the behavior of complex economic variables involved in the monetary transmission mechanism, the FAVAR model proposed by Bernanke et al. (2005) allows better identification of monetary policy shocks. Moreover, it enables the use of unlimited variables to proxy theoretical constructs and helps researchers eliminate the need to arbitrarily choose a specific variable

${ }^{1}$ This mandate is explicitly stipulated in Act No. 23 of 1999 concerning Bank Indonesia, as amended by Act No. 3 of 2004 and Act No. 6 of 2009 in Article 7. 
to represent an economic concept. Third, we use a regional dataset on all 34 provinces in Indonesia. ${ }^{2}$

In the first part of this paper, we measure the asymmetric effects of a common monetary policy shock in Indonesia on regional inflation. Based on the estimates from our province-level structural FAVAR, in the second part, we analyze the reasons for the differential responses to monetary policy. More specifically, we investigate the role of regional structural characteristics in the responses of regional inflation to monetary policy. The rest of this paper is organized as follows. Section 2 presents the methods and data. In Sect. 3, we discuss related literature and the manner in which regional structural characteristics may give rise to regional asymmetries in monetary policy transmission. Section 4 briefly reviews the regional structural characteristics and inflation situation of Indonesian provinces. Section 5 presents the results and discussion, and finally, Sect. 6 concludes the paper.

\section{Literature review: monetary policy transmission and regional structural characteristics}

A voluminous literature has addressed regional transmission of monetary policy. ${ }^{3}$ Most of the studies discuss the topic in relation to advanced countries or regions, mainly the United States (US) and European countries. The study by Toal (1977) is perhaps one of the earliest attempts to bring evidence on asymmetric regional responses to monetary policy, revealing differences in regional responses in the US during 1952-1975. Similarly, the examination by Garrison and Chang (1979) shows a pronounced differential regional impact of monetary and fiscal policy in eight regions of the US during the 1969-1979 period. They find that regions with large concentrations of durable goods manufacturing appeared to see a more substantial impact than agriculture and mining-based regions, where the impact was relatively small. Again, for the US, using state-level data from 1960 to 1978, Garrison and Kort (1983) find that monetary policy actions (together with fiscal policy) shape different changes in regional economic activity.

Unlike earlier studies that use structural reduced-form equations, Carlino and DeFina $(1998,1999)$ apply a structural VAR model and find that the US regions can be categorized into two groups: core regions, which respond to monetary policy actions similarly to the US average response, and noncore regions, which show less sensitive responses. Regarding the sources of the differential state responses, they find that the share of manufacturing appears to be an essential factor in explaining why some regions are more responsive to changes in monetary policy shocks. ${ }^{4}$ In Europe, Arnold and Vrugt (2002, 2004) employ a VAR model and reveal sizable differences in the output responses to monetary policy shocks across provinces in the Netherlands and Germany over the periods from 1973 to 1993 and 1970 to 2000, respectively. Furthermore, they find that those differences are associated with characteristics of the regions' economic structure, such as industry mix, firm size, bank size, and openness.

\footnotetext{
2 The study of Ridhwan et al. (2014) uses a dataset covering only 26 provinces.

${ }^{3}$ Dominguez-Torres and Hierro (2019) provide a rigorous and updated review of a range of empirical works dealing with regional effects of monetary policy.

${ }^{4}$ They also find a weakly significant importance of firm and bank size in regional responses to monetary policy changes.
} 
Empirical studies generally find that asymmetrical effects of monetary policy across regions reflect heterogeneous socioeconomic structures. Indeed, the literature provides several explanations for why the impact of monetary policy can vary across regions. Among several plausible explanations, most studies highlight the following four critical structural characteristics that generate asymmetric territorial effects of monetary policy: (i) heterogeneity in the industrial composition that is sensitive to the interest rate (interest rate channel), (ii) differences in bank credit (credit channel), (iii) differences in regional export intensity, and (iv) the degree of labor market rigidity.

\subsection{Industrial structure or industry mix}

The importance of the industrial structure across regions accentuates the relevance of the interest rate channel of monetary transmission. The effect of a change in the policy interest rate is more significant in regions where the share of interest-sensitive industries in the economy is relatively higher (see, e.g., Taylor 1995; Mishkin 1996). This is because some industries are more interest-sensitive than others. While classifying more interest sensitive industries is an open question, some studies categorize durable and investment goods producers and other highly capital-intensive industries as interest sensitive (Carlino and DeFina 1999).

\subsection{Financial structure: the importance of bank credit}

The operation of the credit channel of monetary policy transmission is premised on the assumption of imperfect substitution of retail bank deposits and loans. Most borrowers cannot access financing sources other than banks. Transmission through the credit channel implies that monetary policy works by affecting bank assets, i.e., loans, in addition to interest rates (Bernanke and Blinder 1992). For example, loosening monetary policy raises the price of collateral and increases banks' equity capital or net worth, allowing them to access more financing sources. As a result, the amount of bank loans available rises since bank reserves and deposits increase, and this eventually affects aggregate demand by accelerating investment and consumption. The responses to monetary policy might differ from one bank to another, depending on the components through which the credit channel operates: the bank's balance sheet, lending capacity, and capital. However, the different reaction of all the credit channel components across individual banks is reflected in the total amount of bank credit disbursed as a financing source in the economy for either consumption or investment. Empirical evidence suggests that the credit channel amplifies the effects of monetary policy on output and prices more forcefully if bank credit is more important in an economy, indicated by a higher ratio of total bank credit to gross domestic product (GDP) (see, e.g., Dornbusch et al. 1998; Cecchetti et al. 1999; Mihov 2001).

\subsection{Differences in regional export intensity}

The importance of regional export intensity for the differential effects of monetary policy is still debated given the mixed empirical evidence. On the one hand, some studies argue that regions with more export-intensive industries appear to be more responsive to monetary policy change. When contractionary policy is implemented, currency appreciation might push export products' prices to rise, reducing domestic firms' competitiveness 
and dragging down demand for exports. By the same logic, currency appreciation might lead to a surge in imports due to the relatively cheaper price of imported goods and smaller markups. The combination of these two effects stemming from currency appreciation eventually worsens net exports, decreasing exports and increasing imports, and might push the domestic price level downward due to the income effect (Hayo and Uhlenbrock 2000). On the other hand, evidence from different studies supports the view that monetary policy effects are less pronounced in highly export-intensive regions (Ber et al. 2001). The central argument of this view is based mainly on the evidence for a supply-side effect that works via the domestic credit market under the free movement of international capital. When domestic financing becomes more expensive due to monetary tightening, exporting firms can access alternative financing from the foreign currency market, from foreign financial institutions or their affiliated parties, and thus do not necessarily reduce their investment. Moreover, exporting firms' financial conditions are less exposed to domestic interest rates since their revenue depends largely on external market conditions.

\subsection{The degree of labor market rigidity}

In the context of monetary policy transmission, labor market rigidity expresses how frequently nominal wages can be adjusted in a given circumstance. As suggested by the baseline new Keynesian business cycle model, when nominal wages can be adjusted less frequently, the response of firms' marginal costs to a monetary policy shock is minimal, which is thus reflected in a weaker inflation response (see, for example Galí 2015). In practice, a group of empirical studies supports this view with different model specifications to explain the precise mechanisms (see, e.g., Zanetti 2007; Christoffel and Kuester 2008; Lechthaler et al. 2010). In general, the studies find that inflation responses to a monetary policy shock are more muted in economies with more rigid labor markets.

\section{Methods and data}

As mentioned in Sect. 1, the final objective of the present study is to evaluate the role of regional structural characteristics in the heterogeneous regional responses to monetary policy shocks. To achieve this goal, we implement a two-step analysis approach, similar to that of Carlino and DeFina (1998) and Ridhwan et al. (2014). First, we estimate the regional effects of monetary policy using a structural FAVAR model. Second, we examine the role of regional structural characteristics in the heterogeneous regional responses to monetary policy changes.

Although previous studies carefully deal with feedback effects among the variables by using standard VARs, they fail to incorporate complex dynamics of the multiple economic variables involved in the monetary transmission mechanism. This condition is well understood as a typical problem of the degree of freedom in VAR models. ${ }^{5}$ To solve this problem, we apply the FAVAR model, which can include a great deal of information.

\footnotetext{
${ }^{5}$ Bernanke et al. (2005) argue that depending on the number of observations, standard VAR models can typically include from approximately six to no more than eight variables; otherwise, the number of parameters to be estimated would rapidly increase with the lags. This limitation often forces VAR modelers to omit important information in the analysis, leading to biased estimates of the VAR coefficients. Furthermore, the limited number of variables can lead to discretionary selection of variables to represent economic concepts (Nurliana et al. 2016).
} 
Typically, FAVAR models contain dozens or even hundreds of variables, making it possible to estimate the effect of monetary policy on a large number of macroeconomic variables. Moreover, in practice, the central banks' monetary policy decision is formulated based on observation of many variables. Thus, to precisely capture the transmission of monetary policy to the real economy, it is crucial to apply a model that can handle extensive information sets to make the identification of monetary policy shocks more reliable (Bernanke et al. 2005; Boivin et al. 2010; Laine 2019).

\subsection{FAVAR model and structural shock identification}

We begin by assuming that $Y_{t}$ is an $M \times 1$ vector of observed economic variables and $F_{t}$ is an $F \times 1$ vector of unobserved or latent factors that contain most of the relevant economic information. The FAVAR model assumes that the dynamic relationship of $Y_{t}$ and $F_{t}$ jointly follows a VAR process (Bernanke et al. 2005), that is:

$$
\left[\begin{array}{c}
F_{t} \\
Y_{t}
\end{array}\right]=\Phi(L)\left[\begin{array}{c}
F_{t-1} \\
Y_{t-1}
\end{array}\right]+v_{t}
$$

where $\Phi(L)$ is a finite-order polynomial in the lag operator and may include a priori constraints such as those found in the structural VAR literature, and $v_{t}$ is the error term with zero mean and covariance matrix. One could refer to as standard VAR in $Y_{t}$ when the terms of $\Phi(L)$, that connect $Y_{t}$ to $F_{t-1}$, are all zero.

Bernanke et al. (2005) assume that the non-observed factors $F_{t}$ and the observable variables $Y_{t}$ can be related to the informational series in $X_{t}$ as expressed in the following equation:

$$
X_{t}=\Lambda^{f} F_{t}+\Lambda^{y} Y_{t}+\varepsilon_{t}
$$

where $\Lambda^{f}$ is the $N \times K$ loading matrix, $\Lambda^{y}$ is the $N \times K$ matrix of coefficients, and $\varepsilon_{t}$ is the $N \times K$ error vector with a zero mean.

We cannot directly estimate Eq. 1 since the $F_{t}$ factors are not observed. Therefore, we apply a two-step approach with principal component analysis (PCA), following Bernanke et al. (2005). The first step involves estimating $\widehat{F_{t}^{1}}, \widehat{F_{t}^{2}}, \ldots, \widehat{F_{t}^{n}}$ which are the first principal components obtained from each group of a series carrying the largest eigenvalue in each category. In the context of our study, the factors summarize all information on inflation dynamics that is excluded from $Y_{t}$. In the second step, we use these factors within the VAR framework, as represented in Eq. 1, to estimate $\Phi(L)$. Specifically, following the lead of Bernanke and Boivin (2003) and Bagliano and Morana (2009), before conducting PCA, we first group the variables under consideration into two categories that represent two different factors affecting inflation: (1) domestic financial system conditions and (2) global economic and financial conditions. We normalize all series to make the values of each series in the data have zero mean and unit variance to reduce the bias toward high variances caused by the multiple measurement units of the series used in PCA. Table 4 in the Appendix contains the list of indicators used in the estimations of the factors.

Then, to preserve the model's economic interpretation, we create a structural form of the FAVAR model. Following Ridhwan et al. (2014), we also define a vector of exogenous variables represented by a factor that contains major global economic information, 
including the industrial production index and price dynamics in the US and China and the international price indices of oil and other commodities.

The corresponding structural model of our FAVAR can therefore be written in the following reduced form:

$$
Y_{t}=A(L) F_{t}+B(L) Z_{t}+\mu_{t}
$$

where $Y_{t}$ is an $N \times 1$ matrix of endogenous variables, $Z_{t}$ is a vector of exogenous variables, $A(L)$ and $B(L)$ are polynomial matrices, and $\mu_{t}$ is a vector of reduced-form disturbances.

We further use the above structural FAVAR (SFAVAR) specification to model economic activity in the 34 Indonesian provinces with a set of endogenous variables for province $i$ as follows:

$$
Y_{t}=f\left(\mathrm{GDP}_{t}^{\text {nat }}, \mathrm{INF}_{t}^{\text {nat }}, \mathrm{POL}_{t}, \mathrm{NER}_{t}, \mathrm{FIN}_{t}, \mathrm{GDP}_{i t}, \mathrm{INF}_{i t}\right)
$$

where $\mathrm{GDP}_{t}^{\text {nat }}$ is aggregate national output, $\mathrm{INF}_{t}^{\text {nat }}$ is aggregate inflation, $\mathrm{POL}_{t}$ is an interest rate variable representing the monetary policy stance, $\mathrm{NER}_{t}$ is the nominal exchange rate, $\mathrm{FIN}_{t}$ is a financial factor, and $\mathrm{GDP}_{i t}$ and $\mathrm{INF}_{i t}$ are regional output and inflation in province $i$, respectively.

Finally, as Christiano et al. (1999) point out, the order of the structural equation variables is critical in determining the identification criterion. Therefore, the restrictions are carefully defined by following Bernanke et al. (2005), who propose the assumption that "slow-moving" variables at the national level [in our case, national GDP (GDP) and INF] do not respond contemporaneously to unanticipated changes in monetary policy while "fast-moving" variables at the national level (in our case, FIN) are allowed to respond contemporaneously to policy shocks. Overall, the identification restriction in our setting refers to economic theories that exclusively limit the contemporaneous structural characteristics as follows:

$$
A_{t}^{-1} B=\left[\begin{array}{ccccccc}
1 & 0 & 0 & 0 & 0 & 0 & 0 \\
* & 1 & 0 & 0 & 0 & 0 & 0 \\
* & * & 1 & 0 & 0 & 0 & 0 \\
* & * & * & 1 & 0 & 0 & 0 \\
* & * & * & * & 1 & 0 & 0 \\
* & * & * & * & * & 1 & 0 \\
* & * & * & * & * & * & 1
\end{array}\right]\left[\begin{array}{c}
\mathrm{GDP}_{t}^{\text {nat }} \\
\mathrm{INF}_{t}^{\text {nat }} \\
\mathrm{POL}_{t} \\
\mathrm{NER}_{t} \\
\mathrm{FIN}_{t} \\
\mathrm{GDP}_{i t} \\
\mathrm{INF}_{i t}
\end{array}\right]
$$

where $*$ indicates unrestricted parameters.

\subsection{Data}

Following the standard literature on monetary policy transmission analysis using FAVAR models, we use various national and regional variables. In total, we exploit data on 45 macroeconomic variables at monthly frequency from January 2010 to December 2019. The endogenous variables at the national level include the nominal policy rate (POL), the GDP growth rate (GDP), CPI inflation (INF), the nominal exchange rate expressed in IDR/USD (NER), and the financial factor (FIN), while the external factor (EXT) denotes 
exogenous variables. ${ }^{6}$ The nominal policy rate (POL) represents the monetary policy stance of the central bank; the nominal exchange rate (NER) and financial factor (FIN) are intermediate variables through which monetary policy is transmitted to the whole economy; both the GDP growth rate (GDP) and CPI inflation (INF) are the final variables affected by monetary policy changes. At the regional level, we include the growth rate of provincial GDP and CPI inflation. Following Wimanda et al. (2011), we convert the GDP series from quarterly to monthly frequency by using the quadratic-matchaverage interpolation technique. In this setting, the GDP growth rate is the percentage change in GDP at time $t$ from $t-12$ according to the constant price in 2010. CPI at the province level is computed as the weighted average of CPI at the city level with this formula:

$$
\mathrm{CPI}_{j t}=\sum_{i \in N_{j}} \omega_{i 2012} \times \mathrm{CPI}_{i t}
$$

where $\mathrm{CPI}_{j t}$ is the CPI of province $j$ at time $t, \mathrm{CPI}_{i t}$ is the CPI of city $i$ at time $t, N_{j}$ is a set of indices for city located in province $j$, and $\omega_{i 2012}$ is the consumption weight of city $i$ based on the 2012 cost of living survey (the "Survei Biaya Hidup" in Indonesian). Then, the CPI inflation at the province level is the percentage change of CPI over twelve months. Data for POL, NER, and INF are collected from Bank Indonesia and the Indonesian Central Bureau of Statistics, respectively.

\section{Regional economic structure and regional inflation in Indonesia}

Indonesia is a spatially diverse nation with hundreds of ethnic groups and cultures and different natural resource endowments and demographic structures spread throughout its 34 provinces. Known as one of the most heterogeneous countries on earth and the world's largest archipelago, Indonesia has long faced regional development disparity issues (Resosudarmo and Vidyattama 2006).

For decades, disparities in Indonesia's regional development between the more prosperous west and the poorer east have been persistent. Despite the findings by Hill et al. (2008) of a more even spatial distribution in economic growth, ${ }^{7}$ the west/east economic disparities were still visible in the 2010-2019 period, approximately one decade after the decentralization policy was first implemented in 2000. Provinces located in the western area of Indonesia (17 provinces in the Sumatra and Java-Bali regions) contribute approximately $81 \%$ of national GDP (where 7 provinces in the Java-Bali region account for approximately $60 \%$ of national GDP), where 17 provinces in the eastern part share only less than $20 \%$ of national GDP (Table 1 ).

Different underlying factors, such as resource endowments, climate and geographical location, shape Indonesian provinces' regional economic structures. Economic activities in the Java-Bali region are highly supported by its manufacturing industries. For example, almost half (43\%) of GDP in West Java is contributed by manufacturing industries.

\footnotetext{
$\overline{{ }^{6} \text { All series are seasonally adjusted, unit root tests are applied, and data transformation is implemented to ensure station- }}$ arity.

${ }^{7}$ Hill et al. (2008) find that the poorest regions, located mainly in the eastern area, have broadly achieved economic growth rates comparable to those of the regions in the western area and the national average, as shown in Table 1.
} 


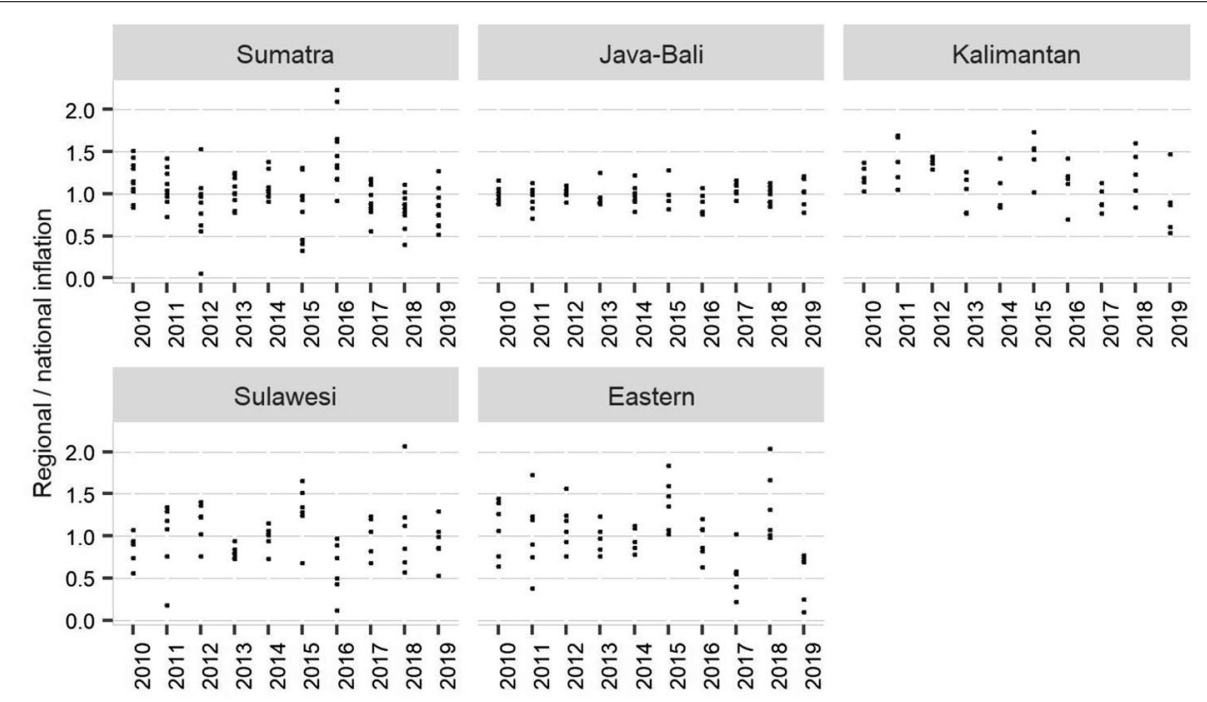

Note: The vertical axis shows the value of regional inflation divided by national inflation for each year.

Fig. 1 Regional inflation relative to national inflation. The vertical axis shows the value of regional inflation divided by national inflation for each year

Taken together, the average share of manufacturing to GDP in four provinces of Java, excluding Jakarta and Yogyakarta, is $36 \%$. As the home of large manufacturing firms, the region is also equipped with corresponding physical capital such as infrastructure and better human capital with a highly educated labor force. Provinces in Java also have a higher dependency on bank lending to finance their manufacturing industries than other Indonesian provinces. The ratio of bank lending to GDP in Jakarta, the capital city of the country, is up to $74 \%$. This high ratio in Jakarta is not surprising due to several factors: the enormous size of its economy, its higher level of financial literacy in society and greater access to the financial system, and its status as the capital city where most of the large banks are located. In the rest of the provinces in Java, the bank lending to GDP ratio reaches $40 \%$, higher than the average ratio in Sumatra (30\%), Kalimantan (34\%), Sulawesi (35\%), and provinces in the eastern part of Indonesia (34\%).

While economic activities in Java largely depend on the manufacturing sector, the rest of the regions rely on the primary sector, notably the agriculture and mining sectors. For example, approximately $37 \%$ of economic value added in three provinces of Sulawesi (Gorontalo, Central and West Sulawesi) comes from value added in the agriculture sector. Similarly, the mining sector in North, East, and South Kalimantan accounts for approximately $36 \%$ of total GDP, on average. Additionally, some non-Java-Bali provinces are more heavily reliant on international trade activities due to their international comparative advantages in the extractive industries and strategic geographical position. For example, the export value of Riau Islands province in the Sumatra region, which shares a border with Singapore, accounts for $82 \%$ of its GDP. Similarly, a higher export to GDP ratio is typical for natural resource-rich provinces such as South Kalimantan (72\%), East 
Kalimantan (62\%), West Papua (55\%), Bangka Belitung (51\%), and Riau (39\%). As discussed in Sect. 2, these different economic structures ${ }^{8}$ can drive asymmetric monetary transmission across regions.

In addition to highlighting the different characteristics of regional economic structures, it is also of interest to document regional inflation patterns and briefly introduce recent initiatives to control regional inflation in Indonesia. Figure 1 plots the ratio of provincial to national inflation for every year. ${ }^{9}$ Similar to the spatial distribution of GDP, there is also a prolonged, unique pattern of regional inflation in Indonesia: inflation in the Java-Bali region tends to closely align with national inflation, whereas inflation outside the Java-Bali region is less synchronized..$^{10}$ For example, some provinces in Sumatra, one province in Sulawesi, and one province in the eastern region recorded inflation twice as high as national inflation in 2016 and 2018, respectively. Moreover, the average ratio of provincial to national inflation in Sumatra and the eastern region was 1.5 in 2016 and 1.3 in 2018, while the ratio was 0.85 and 0.98 in Java in the respective years.

The similarity in inflation rates of provinces in Java-Bali region with the national inflation is inextricably linked to the state of the industrial structure and infrastructure of the region, both of which affect the cost structure of production. The Java region's manufacturing-based industrial structure is particularly sensitive to the interest rate movements. As a result, the fluctuation of the inflation rate in Java is more closely related to national inflation, which is largely influenced by the monetary policy. Furthermore, better infrastructure and logistics in Java resulted in decreased production costs, resulting in less erratic pricing dynamics. As a result, price adjustments will be expected to be more constrained, resulting in a more-steady inflation rate. This is consistent with the literature, which claims that rising production costs and supply shocks give rise to inflation in emerging countries.

The aforementioned illustration of the substantial regional inflation differential not only helps us understand how regions respond differently to monetary policy but also highlights the complexity of controlling inflation in regionally diversified Indonesia. Some studies find that the source of inflation in Indonesia is not only the demand side but also irregularities on the supply side, such as disturbances in the production and distribution of food commodities (see, e.g., Alamsyah et al. 2001; Affandi et al. 2011; Tirtosuharto and Adiwilaga 2013; Purwono et al. 2020), complicating inflation control programs. Therefore, coordinated policies from the central bank and governments (both national and regional) are required to control regional inflation effectively. One historical milestone of inflation control policy in Indonesia, especially at the regional level, was the establishment of the Regional Inflation Controlling Team (RICT), known as Tim Pengendalian Inflasi Daerah (TPID) in 2008. ${ }^{11}$ Under this coordination, the central bank

\footnotetext{
${ }^{8}$ These include the less distinctive structures of the shares of the construction sector, consumption, and investment in GDP as well as the unemployment rate across provinces.

9 A ratio of 1 means provincial inflation is equal to national inflation in a given period.

10 Purwono et al. (2020) also find that the inflation rates of cities in Java-Bali region are lower than outside Java-Bali cities during the period of December 2014-2018.

11 The main duties of the team include collecting the price data of selected goods, expanding local capacity in producing foodstuffs, improving the logistics system, and planning and executing regional policy to control regional inflation. The coordinated inflation control policy was further strengthened by the establishment of a National Inflation Controlling Team (NICT) or Tim Pengendalian Inflasi Nasional (TPIN) in the 2017 President's Decree of the Republic of Indonesia No. 23.
} 


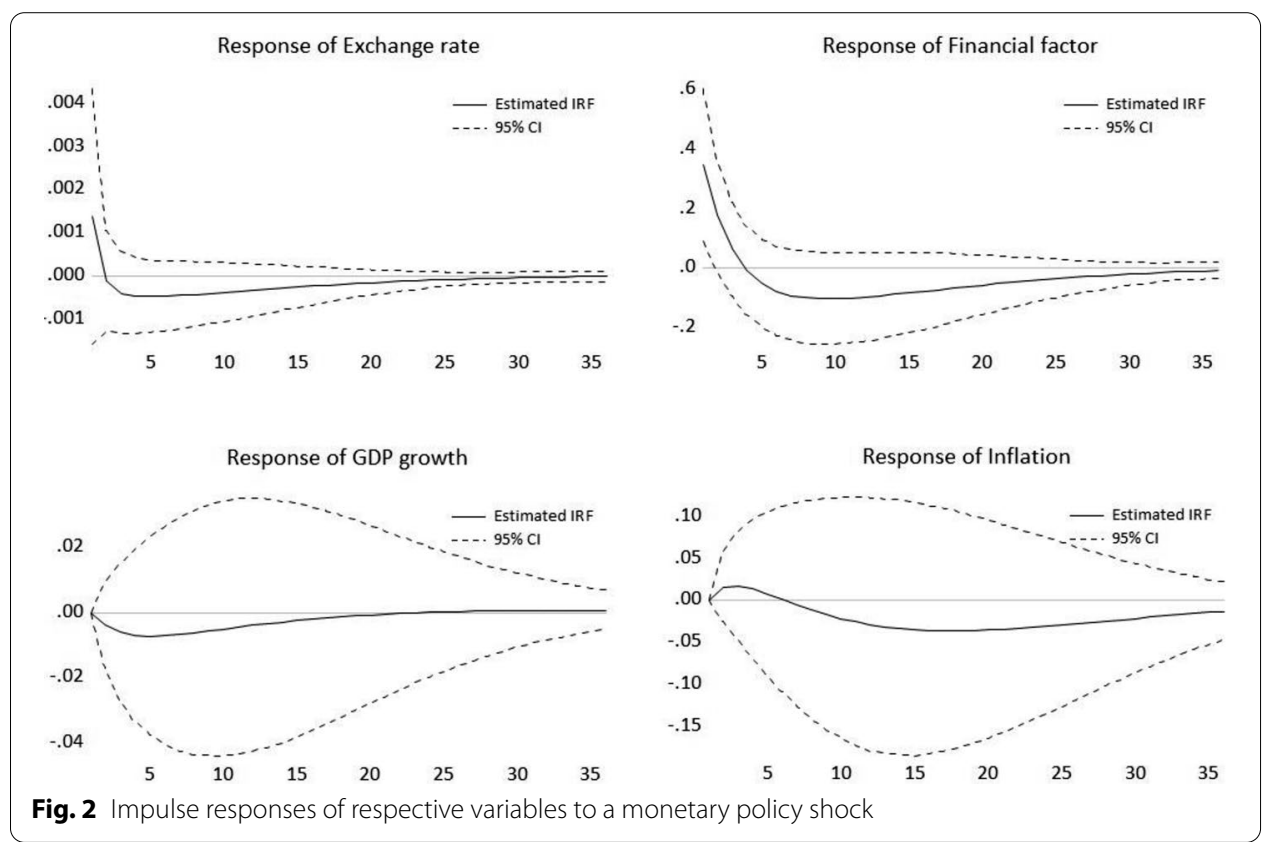

implements monetary policy to anchor inflation expectations, while the government's sectoral policies address distortions on the supply side.

\section{Results and discussion}

\subsection{Heterogeneous effects of a monetary policy shock on regional inflation}

The estimated coefficients and factors in the SFAVAR model are shown in Table 5 in the Appendix. ${ }^{12}$ The coefficients of GDP growth, inflation, and the nominal exchange rate are consistent with expectations from theory. Both GDP growth and inflation decline following monetary policy shocks in the previous period, while the nominal exchange rate appreciates.

We also report the impulse response functions in Fig. 2. The responses are generally of the expected sign and magnitude. The immediate responses to a hike in nominal policy rates are the appreciation of nominal exchange rate and the decrease of financial factor. Then, GDP growth rate gradually falls. However, the initial consequence of rate of inflation against a nominal interest hike is a jump of rate of inflation, which is not consistent to monetary theory but has been observed in many studies on monetary transmission mechanism called "Price Puzzle".

Although there is a price puzzle observed here, the response to monetary tightening is eventually followed by a drop in inflation pressure from the seventh month onward as the market expects slowing demand. The existence of a price puzzle in monetary transmission, that is, a rise in prices in the short term due to positive shocks from the 


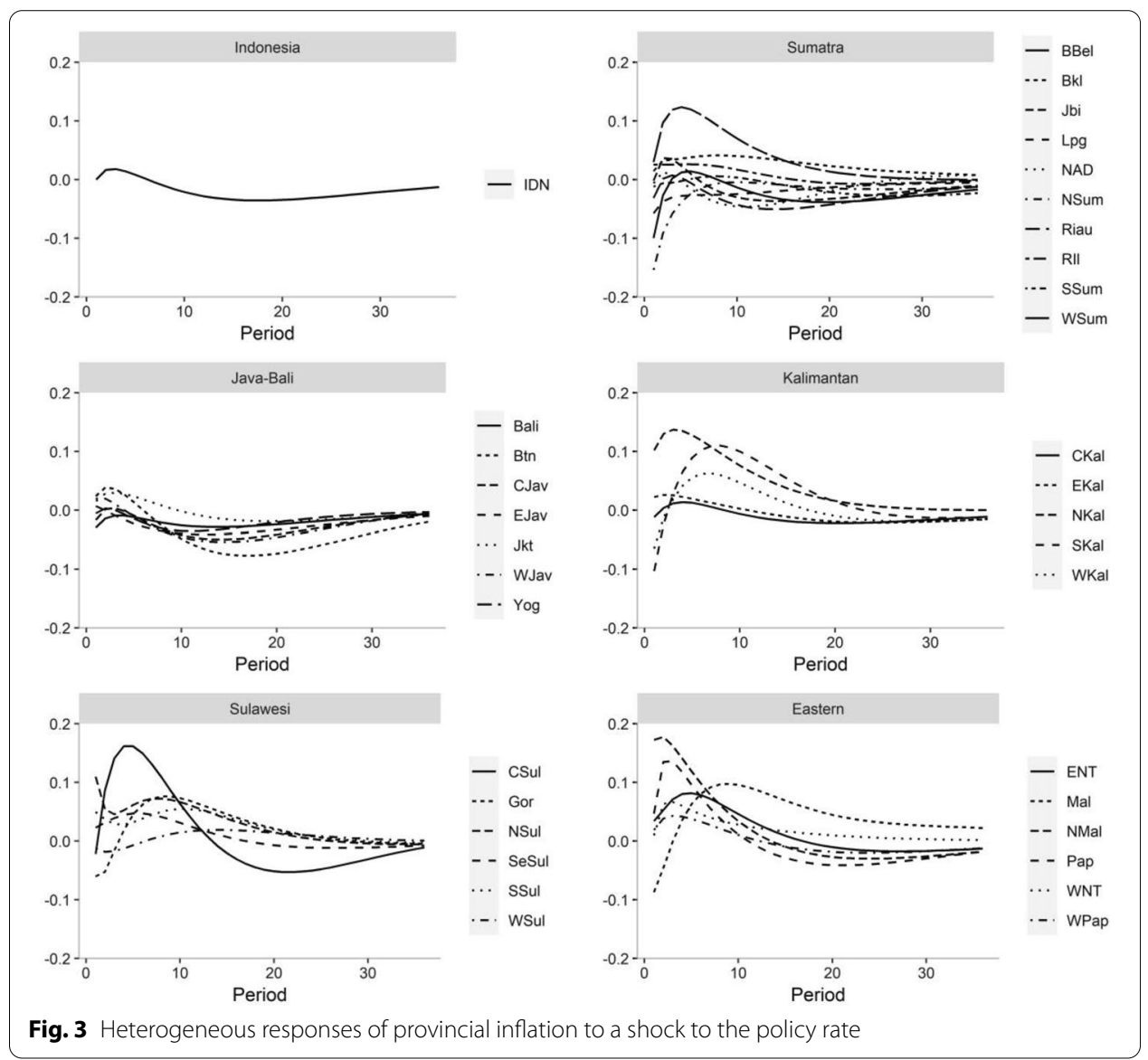

monetary policy contraction, has also been evidenced in other countries, as documented by Ramey (2016). ${ }^{13}$ For the case of Indonesia, Kusmiarso et al. (2002), Harahap et al. (2013), and Nurliana et al. (2016) also show a price puzzle in monetary transmission.

After implementing the SFAVAR at the national level, we proceed with our analysis at the province level as expressed in Eq. 4 to capture the contemporaneous response of inflation in each province to a common monetary policy shock. In Fig. 3, we plot the impulse responses from the SFAVAR analysis at both the national and province levels. All graphs share the same scale on the vertical axes to facilitate comparability. The figure demonstrates evidence of heterogeneous effects of a common monetary shock across Indonesian regions, where provinces on the Java and Bali Islands have very similar responses to the national response.

Based on the impulse response of each province, we construct the measurement of the regional inflation response to monetary policy shocks. We include both the magnitude and length to gauge two measurements of a regional inflation response to monetary policy. The first measure is computed by multiplying the peak of the impulse response with the corresponding time taken to reach the peak, as represented by Eq. 7:

13 Concerning the impact of monetary policy shocks on price, the price puzzle is not always present. For example, one group of studies finds a price puzzle (e.g., Christiano et al. 1999; Bernanke et al. 2005), but other researchers do not observe it (e.g., Del Negro et al. 2007). For a detailed discussion on the price puzzle, please refer to Ramey (2016). 


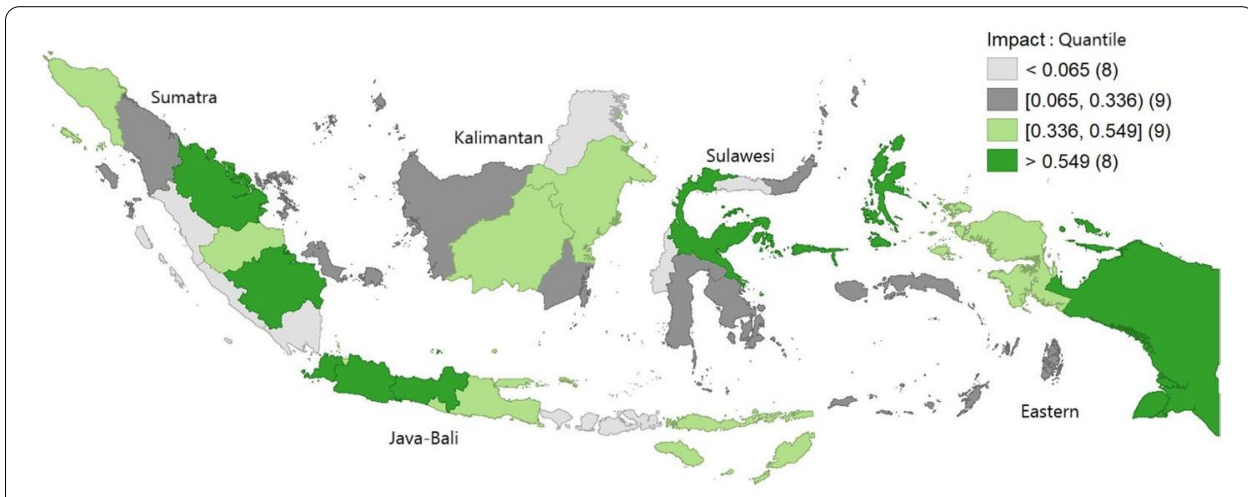

Fig.4 Quantile map of monetary policy impacts on regional inflation

Impact $=$ Maximum response $\times$ Time to peak

We call this measure the monetary policy impact. The second measure is monetary policy efficiency, where we divide the peak of the impulse response by the corresponding time taken to reach the peak, as shown in Eq. $8:{ }^{14}$

$$
\text { Efficiency }=\frac{\text { Maximum response }}{\text { Time to peak }}
$$

Next, in Fig. 4, we visualize the geographical distribution of the monetary policy impact on regional inflation by using quantile classification. We observe an expected pattern from this mapping: all provinces in Java (except Jakarta) show a larger than median impact. This island is home to large manufacturing industries, with the share of the manufacturing sector on the island accounting for nearly $70 \%$ of national manufacturing industry output (based on real GDP in 2019). Furthermore, the size of bank lending on the island contributes $62 \%$ to total national bank lending (2019), implying a significant role of these two regions in the national banking industry. Similar patterns are also observed in Ridhwan et al. (2014), where manufacturing regions in Java and Sumatra are found to be more sensitive to monetary policy shocks.

\subsection{Regional economic structure and monetary transmission}

Up to this point, we have shown our findings from the SFAVAR analysis of differences in regional responses following monetary policy actions. Next, we examine regional factors that explain the variation in the reaction of regional inflation to monetary policy changes. More specifically, our goal is to answer the following question: to what extent do regional structural features explain the heterogeneity in regional inflation responses to monetary policy shocks? To achieve this goal, we implement a cross-sectional ordinary least squares (OLS) estimation as follows:

\footnotetext{
${ }^{14}$ Since we evaluate monetary policy transmission in relation to regional inflation, the peak impulse response is expected to be a negative number. Thus, we multiply the number by -1 to obtain the positive direction of the measurement; the higher the number is, the larger the monetary policy impact or efficiency.
} 


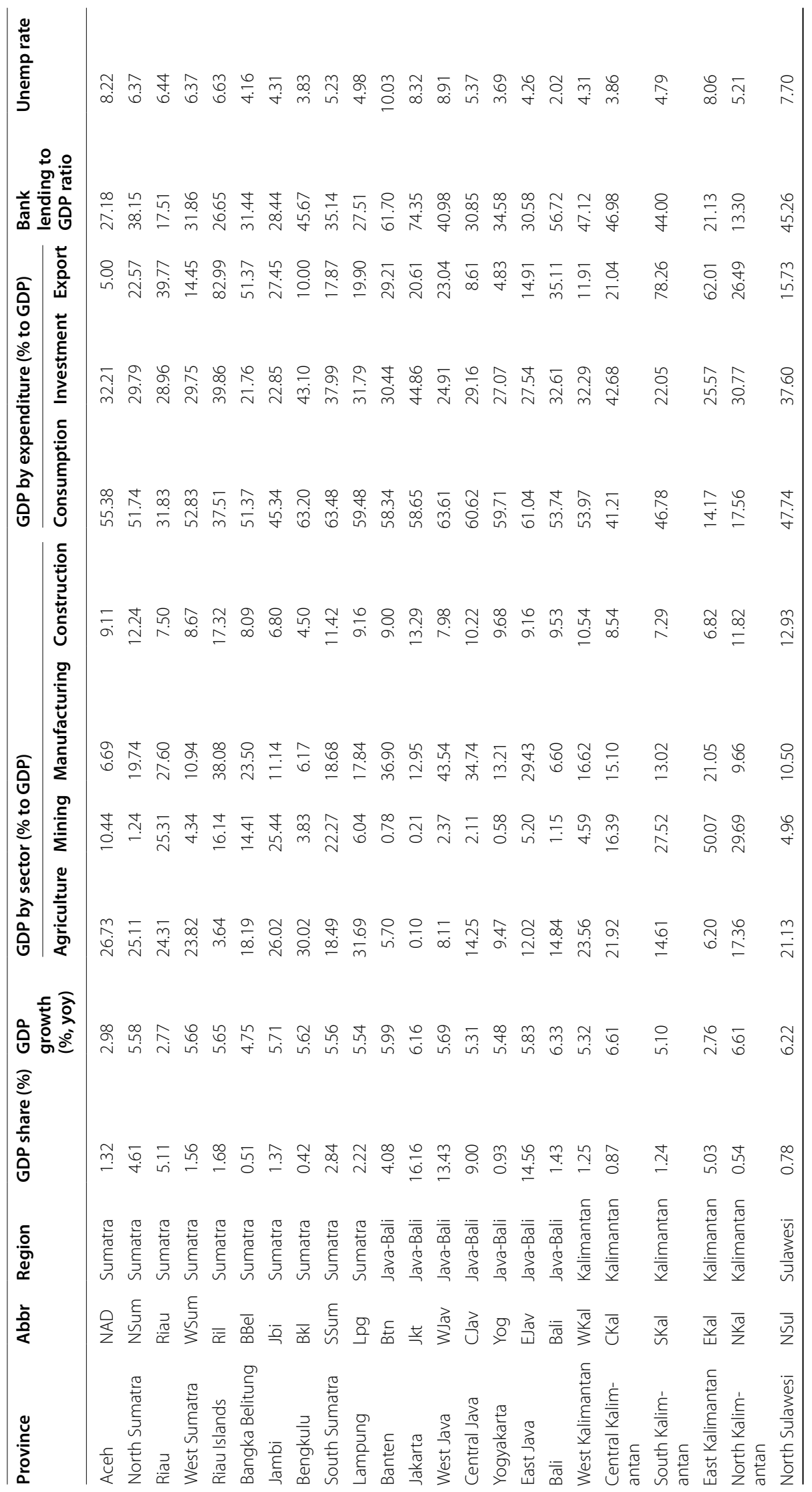




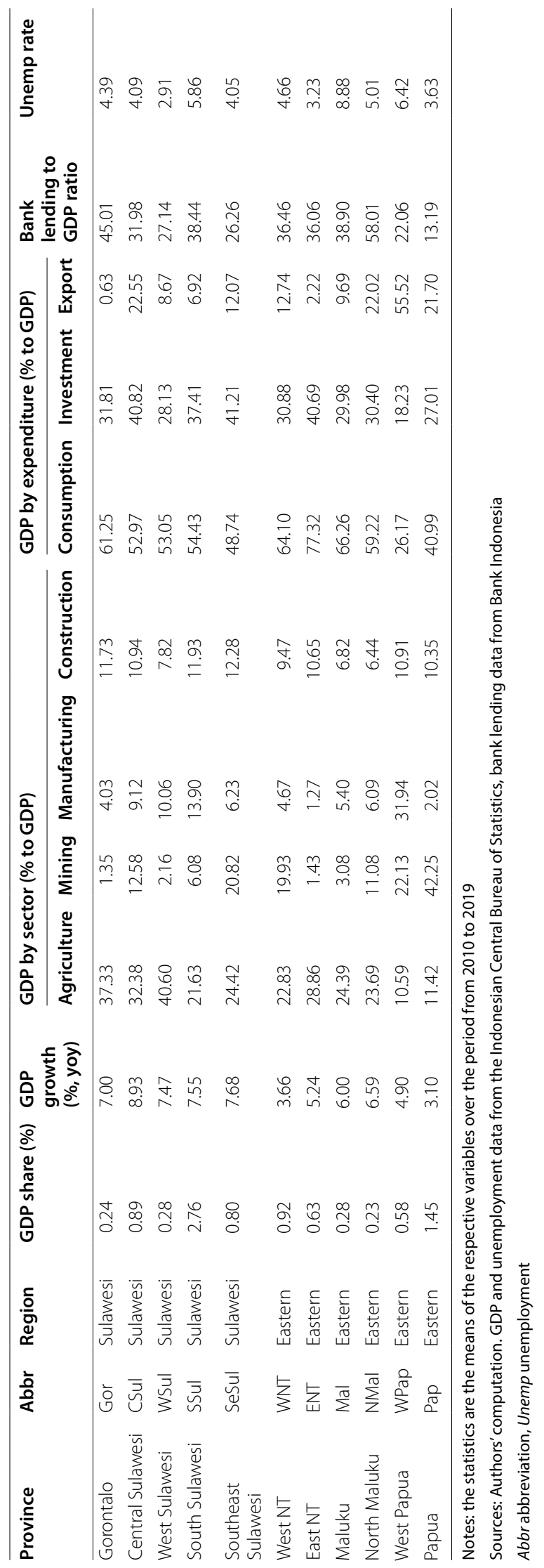




$$
V=\beta_{0}+\Sigma \beta_{j} Z_{t}+\varepsilon, j=1, \ldots, n
$$

where the dependent variable $V$ is the measure of monetary policy impact and monetary policy efficiency, respectively, derived from the estimated impulse responses based on the previous FAVAR model, $\beta_{0}$ is the intercept of the model, $Z_{t}$ corresponds to the $j$ th explanatory variable of the model representing regional economic structures, and $\varepsilon$ is the random error with expectation 0 and variance $\sigma^{2}$.

The existing literature provides a good background for the selection of regional features that can explain the different responses to monetary policy actions. For example, Arnold and Vrugt $(2002,2004)$ point out the importance of the industrial composition to explain the regional transmission of monetary policy in the Netherlands and Germany. For the case of Greece, Anagnostou and Papadamou (2016) find that regions' sensitivity to interest rate shocks is related to regional characteristics such as the share of particular industries in GDP. Finally, Ridhwan et al. (2014) also mention that industrial composition explains the variation in the regional impacts of monetary policy changes, corroborating the pertinence of the interest rate and credit channels for monetary policy transmission in Indonesia.

Referring to the previous literature and discussion in Sect. 3, we consider several indicators representing the regional economic structure that might explain regional heterogeneity in the response of regional inflation to monetary policy shocks. The first two variables are the share of manufacturing to GDP and the share of mining sector to GDP. Commonly used in previous studies, these two variables are used to capture regional differences in capital-intensive industries or industrial mixes. As mentioned earlier, these variables reflect the way that monetary policy is transmitted via the interest rate channel. The third and fourth variables are the bank lending to GDP ratio and the export share in GDP, respectively. While the former reflects the relative importance of bank lending to the provincial economy, the latter demonstrates regional openness. According to the literature, these variables have information on how the credit and exchange rate channels of monetary policy operate at the regional level. As shown in Table 1, these four initial variables represent different regional economic structures that potentially give rise to the heterogeneity in regional responses to monetary policy. We also include the manufacturing industry's annual growth rate to capture the importance of manufacturing in the regional economy. Moreover, recent studies have shown the relevance of investigating the spatial dependence of regional inflation (see, e.g., Yesilyurt and Elhorst 2014; Aginta 2020b). Thus, to capture the role of spatial externalities, we include the spatial lag of inflation, that is, neighboring provinces' inflation rates. More precisely, we compute the spatial lag of the inflation rate by applying a $k$-nearest neighbors (KNN) weight matrix $(\mathrm{W})$. The neighbors of a province are the four nearest provinces based on the Euclidean distance. ${ }^{15}$ Finally, to capture labor market flexibility, we use the standard deviation of the regional unemployment rate, which reflects the labor market's sensitivity to macroeconomic shocks.

${ }^{15}$ We use a 4-nearest-neighbors weight matrix as the baseline scenario. 
Table 2 Estimated equations evaluating the role of the economic structure in cross-province variation in monetary policy impacts

\begin{tabular}{llllll}
\hline Variables & \multicolumn{6}{l}{ Dependent variable: cross-province monetary policy impact } & \\
\cline { 2 - 6 } & $\mathbf{( 1 )}$ & $\mathbf{( 2 )}$ & $\mathbf{( 3 )}$ & $\mathbf{( 4 )}$ & $\mathbf{( 5 )}$ \\
\hline $\begin{array}{l}\text { Manufacturing share } \\
\text { (\% of GDP) }\end{array}$ & $0.022^{\mathrm{c}}(0.006)$ & $0.024^{\mathrm{c}}(0.006)$ & $0.025^{\mathrm{c}}(0.005)$ & $0.024^{\mathrm{c}}(0.006)$ & $0.022^{\mathrm{c}}(0.005)$ \\
$\begin{array}{l}\text { Mining share (\% of } \\
\text { GDP) }\end{array}$ & $0.021^{\mathrm{c}}(0.007)$ & $0.024^{\mathrm{c}}(0.007)$ & $0.029^{\mathrm{c}}(0.007)$ & $0.028^{\mathrm{c}}(0.007)$ & $0.024^{\mathrm{c}}(0.006)$ \\
$\begin{array}{l}\text { Bank lending to GDP } \\
\text { ratio }\end{array}$ & $0.010^{\mathrm{a}}(0.005)$ & $0.011^{\mathrm{b}}(0.005)$ & $0.012^{\mathrm{b}}(0.005)$ & $0.010^{\mathrm{a}}(0.005)$ & $0.011^{\mathrm{b}}(0.005)$ \\
$\begin{array}{l}\text { Foreign export share } \\
\text { (\% of GDP) }\end{array}$ & $-0.011^{\mathrm{b}}(0.004)$ & $-0.011^{\mathrm{c}}(0.004)$ & $-0.012^{\mathrm{c}}(0.003)$ & $-0.012^{\mathrm{c}}(0.004)$ & $-0.009^{\mathrm{b}}(0.004)$ \\
$\begin{array}{l}\text { Manufacturing growth } \\
\text { (\%, yoy) }\end{array}$ & & $0.035^{\mathrm{b}}(0.015)$ & $0.028^{\mathrm{a}}(0.014)$ & $0.031^{\mathrm{b}}(0.015)$ & $0.036^{\mathrm{b}}(0.014)$ \\
$\begin{array}{l}\text { Inflation in neighbor } \\
\text { provinces }\end{array}$ & & & $-0.422^{\mathrm{b}}(0.189)$ & $-0.382^{\mathrm{a}}(0.200)$ & \\
$\begin{array}{l}\text { SD of unemployment } \\
\text { rate }\end{array}$ & & & & $0.102(0.148)$ & \\
$\begin{array}{l}\text { Inflation } \\
\text { Constant } \\
\text { Observations } \\
\text { R-squared }\end{array}$ & $-0.350(0.263)$ & $-0.618^{\mathrm{b}}(0.268)$ & $1.381(0.930)$ & $1.164(0.991)$ & $0.239(0.526)$ \\
\hline
\end{tabular}

Robust standard errors in parentheses

a,b,c Significance at the $10 \%$ level, $5 \%$ level, and 1\% level respectively. Source: Authors' calculation

Table 2 shows the results of the regression on monetary policy impacts. Similar to the findings from previous studies, the results reveal that four variables related to the regional economic structure are statistically significant in affecting the regional inflation response to monetary policy shocks (see Model 1). First, both the share of manufacturing to GDP and the mining sector's share to GDP have a positive effect on the regional impact of monetary policy. In the literature on monetary policy transmission, this finding supports the view that regional differences in industrial composition play an important role in the differential effects of monetary policy. The finding also suggests that the interest rate channel of monetary policy in Indonesia works reasonably well. Second, we find that the bank lending to GDP ratio positively affects the impact of monetary policy on regional inflation. As discussed earlier in Sect. 3, this result confirms the relevance of a credit channel in monetary policy transmission in Indonesia. Third, the estimated coefficient of the export share to GDP is negative, suggesting that the impact of monetary policy is lesser in export-dependent regions. This finding supports the view that the effects of monetary policy are less pronounced in highly export-intensive regions (Ber et al. 2001). Exporting firms' real investment does not necessarily decline in the face of a higher real interest rate from tightening monetary policy. Exporting firms can access foreign currency credit because they are usually part of a larger trade network and are thus more likely to have contacts and a reputation in foreign credit markets. Additionally, they can obtain trade credit from suppliers or customers abroad. Therefore, when the 
domestic real interest rate is high, exporting firms may continuously finance their investment by raising foreign currency loans (or foreign currency-denominated credit). For this reason, exporting firms' income might not be negatively affected by tighter monetary policy. This stable income of exporting firms leads to more persistent aggregate demand in regions that are more export intensive. As a result, the impact of monetary policy on inflation is lower in export-intensive regions.

In Models 2, 3, and 4, we include more variables to show the robustness of the four regional economic structure variables. All models show the consistency of the estimates of the four variables, in both sign and magnitude, suggesting their robustness. Moreover, the improvement in the R-squared to approximately 55\% in Models 3 and 4 reflects the importance of our additional variables in explaining the sources of regional heterogeneity in monetary policy impacts. For instance, we find that manufacturing growth has a positive effect on the monetary policy impact, re-emphasizing the role of interest-sensitive industries mentioned before. Additionally, we reveal the importance of geographical externalities, which is new evidence that has never been uncovered in previous studies. Consistent with our expectation, we find a significant negative effect of rate of inflation in neighboring provinces on the impact of monetary policy. This finding indicates that the impact of monetary policy is smaller when the province is spatially surrounded by the neighboring provinces which suffer from high inflation. This finding further implies spatial monetary transmission mechanism where price shock transmits from one province to another. Therefore, the higher the rate of inflation in neighboring provinces, the smaller the impact of monetary policy on that province. We also found as shown by Model 5 that the coefficient of inflation of the province is also statistically significant and negative. This negative sign can be explained by the notion of inflation inertia (Fuhrer and Moore 1995; Mankiw 2001). Inertia in the inflationary process means that it takes longer to bring inflation down to the target if output costs, such as wages, are not easily adjusted due to high inflation in the past. Therefore, if inflation displays inertia, it is natural to expect that the monetary policy impact on inflation is smaller when the inflation rate is high. Wimanda et al. (2011) find significant inertia when analyzing Indonesia's inflation by using a hybrid version of the new Keynesian Phillips curve (NKPC).

Finally, despite the coefficient having the predicted sign, we find no substantial effects of labor market flexibility on regional monetary policy impact. We propose two possible reasons for this finding: first, the standard deviation of unemployment as a measure of labor market flexibility is far from perfect, and second, even if the measurement is adequate, labor market conditions in Indonesia are not significantly diverse among regions, in contrast to those in the cross-country samples used in previous studies. In summary, our findings favor the literature that emphasizes the role of the regional economic structure in the heterogeneity of regional responses to monetary shocks.

In the second regression, we run another cross-provincial regression with the efficiency of monetary policy as a dependent variable. We separate the efficiency of monetary policy from the total impact of monetary policy to consider the diverse consequences of monetary policy observed in Fig. 3. The figure shows that it takes almost 
Table 3 Estimated equations evaluating the role of the economic structure in cross-province variation in monetary policy efficiency

\begin{tabular}{lllll}
\hline Variables & \multicolumn{4}{l}{ Dependent variable: cross-province monetary policy efficiency } \\
\cline { 2 - 5 } & $\mathbf{( 1 )}$ & $\mathbf{( 2 )}$ & $\mathbf{( 3 )}$ & $\mathbf{( 4 )}$ \\
\hline Manufacturing share (\% of GDP) & $-0.002^{\mathrm{b}}(0.001)$ & $-0.001^{\mathrm{a}}(0.001)$ & $-0.002^{\mathrm{a}}(0.001)$ & $-0.002^{\mathrm{b}}(0.001)$ \\
Construction share (\% of GDP) & $0.005^{\mathrm{b}}(0.002)$ & $0.005^{\mathrm{a}}(0.003)$ & $0.005^{\mathrm{b}}(0.003)$ & $0.005^{\mathrm{b}}(0.003)$ \\
Domestic export share (\% of GDP) & $-0.001^{\mathrm{c}}(0.000)$ & $-0.001^{\mathrm{c}}(0.000)$ & $-0.001^{\mathrm{c}}(0.000)$ & $-0.001^{\mathrm{c}}(0.000)$ \\
Investment share (\% of GDP) & $-0.004^{\mathrm{c}}(0.001)$ & $-0.004^{\mathrm{c}}(0.001)$ & $-0.005^{\mathrm{c}}(0.001)$ & $-0.005^{\mathrm{c}}(0.001)$ \\
Foreign import share (\% of GDP) & $0.001^{\mathrm{b}}(0.000)$ & $0.001^{\mathrm{b}}(0.000)$ & $0.001^{\mathrm{b}}(0.000)$ & $0.001^{\mathrm{b}}(0.000)$ \\
Changes in housing price (\%) & $0.028^{\mathrm{c}}(0.009)$ & $0.025^{\mathrm{b}}(0.010)$ & $0.027^{\mathrm{b}}(0.010)$ & $0.024^{\mathrm{b}}(0.010)$ \\
SD of GDP growth rates & $-0.006^{\mathrm{c}}(0.002)$ & $-0.007^{\mathrm{c}}(0.002)$ & $-0.006^{\mathrm{c}}(0.003)$ & $-0.007^{\mathrm{c}}(0.002)$ \\
GDP per capita & $-0.001(0.001)$ & & & \\
Log (GDP) & & $-0.005(0.006)$ & & \\
Mining share (\% of GDP) & & & $-4 . \mathrm{E}-04(0.001)$ & \\
Service share (\% of GDP) & & $0.100(0.091)$ & $0.048(0.067)$ & $0.080(0.080)$ \\
Constant & $0.043(0.065)$ & 34 & 34 & 34 \\
Observations & 34 & 0.592 & 0.589 & 0.588 \\
R-squared & 0.613 & & & \\
\hline
\end{tabular}

Robust standard errors in parentheses

a,b,c Significance at the $10 \%$ level, $5 \%$ level, and $1 \%$ level, respectively. Source: Authors' calculation

36 months for the impulse response to die out in some provinces while it takes only 12 to 15 months to do so in some other provinces. It also shows that the impulse response quickly peaks and dies out faster in some provinces but slowly peaks and dies out more gradually in some other provinces. The diversity of the shape of the impulse response functions indicates that the determinants of the speed or efficiency of monetary policy transmission could be different from those of their total impact. For this reason, the efficiency of monetary policy is defined as the maximum value of the impulse response divided by the number of months that it takes for the impulse response to peak.

The regression outcome is shown in Table 3. The $R$-squared, 61.3\% for Model 1 and approximately $60 \%$ for others, is fairly good since this is a cross-sectional regression. We examine six variables combined with some other variables to show the robustness of these six variables. The outcome shows different determinants from those of the outcomes of the regression on the total impact of monetary policy discussed before. First, foreign imports, the share of foreign imports divided by provincial GDP, are significant with a positive sign. Monetary policy affects the exchange rate and therefore the prices of imported goods. Monetary policy seems to have a quick effect on inflation in provinces where imported goods account for a large share of consumption. This finding suggests that the exchange rate channel is effective in monetary policy transmission in Indonesia.

Secondly, on the other hand, the shares of investment to GDP and share of manufacturing sector to GDP are statistically significant but negative with respect to monetary policy efficiency. Possible reason for a negative sign is that manufacturing sector share to GDP and investment share to GDP are both sensitive to bank lending. Therefore, monetary policy affects manufacturing firms and investment through a bank lending channel. An interest rate hike has a large impact on manufacturing sector and investment 
spending. However, the impact of an interest hike is slowly priced-in to an increase in bank lending rate. This is because banks usually adjust their lending rates-following the change in monetary policy-only when borrowers such as manufacturing firms apply for new loans for new investments. In addition, it takes time for banks to undertake credit assessment and finalize the new loan contracts. Consequently, the impact of monetary policy is large but it takes time to materialize the full impact when the province has a large share of manufacturing sector and investment share. In other words, the effects of monetary policy on the real economy are slower in provinces with high manufacturing and investment spending shares to GDP, as shown by the negative signs of the coefficients.

The third finding is that provincial housing prices are statistically significant and positive. This finding does not indicate a causal relationship but shows a positive association between the efficiency of monetary policy and housing prices. Theory implies a causal link not from monetary policy efficiency to housing prices but rather the other way around; i.e., monetary policy has a quick effect in provinces where housing prices are rising since the housing sector is heavily credit intensive and its credit disbursement is quick. This explanation is also true in relation to the statistically significant and positive sign of the construction industry share to GDP.

Apart from the findings above, the regression outcome shows that monetary policy is very slow when GDP growth fluctuates and the share of domestic exports in GDP is high, both indicated by a statistically significant negative sign. Monetary policy may not have a quick impact in provinces where the economy experiences large fluctuations and therefore is subject to a high degree of uncertainty. However, it is hard to find a possible reason for the statistically significant and negative sign for the domestic export share to GDP. One of the possible reasons is that bank credit is not as sensitive for those companies that are expanding exports because an increase in domestic export sales reduces the companies' risk premium and improves their creditworthiness.

\section{Conclusion}

Evidence shows that more often than not, regions within a country respond differently to aggregate macroeconomic shocks such as monetary policy changes. This paper analyses the link between the regional economic structure and heterogeneity in the regional response to monetary policy in Indonesia, the largest developing economy in the Southeast Asia region and one that displays marked cross-regional economic disparities. By employing the SFAVAR modeling approach proposed by Bernanke et al. (2005), which combines a standard VAR with factor analysis, we quantitatively demonstrate the heterogeneous regional responses to monetary policy across the 34 provinces of Indonesia by using monthly data from 2010:1 to 2019:12. Spatially, we find that most provinces in the Java-Bali regions have responses similar to the national responses. This pattern is very similar to the characteristics of regional inflation in Indonesia, where the inflation rates of provinces in the Java-Bali region tend to behave more line with national inflation. The monetary policy impact in the Java-Bali region is also higher than the crossregional average impact, owing to the significant dependency on manufacturing and banking activities in the regional economy. 
This paper further investigates the sources of those heterogeneous regional responses by focusing on regional structural characteristics. To facilitate the analysis, two measurements of the regional inflation response to monetary policy shocks are formulated based on each province's impulse response. The first measure is called the monetary policy impact, computed by multiplying the peak of impulse response with the corresponding time taken to reach the peak. The second measure is monetary policy efficiency, where we divide the peak of the impulse response by the corresponding time taken to reach the peak.

In relation to the impact of monetary policy, our findings support the common conclusion that differential cross-regional responses to monetary policy actions can be primarily explained by the regions' economic structure. More specifically, we find that the impact of monetary policy is positively affected by the share of the manufacturing and mining industries to GDP as well as the bank lending to GDP ratio. On the other hand, the impact of monetary policy is more pronounced in provinces with a higher export to GDP ratio. We also find other significant sources of heterogeneity: the growth rate of the manufacturing industry and the spatial lag of inflation. While the former variable underscores the importance of manufacturing industries, the latter stimulates new discussions on the relevance of spatial externalities of inflation across Indonesian provinces and thus offers an avenue for further studies.

Regarding monetary policy efficiency, we find that monetary policy transmission to regional inflation is more efficient when the share of foreign imports to GDP is high, implying the functioning of the exchange rate channel. We also find a positive association between monetary policy efficiency and housing prices and the share of construction sector to GDP, while monetary policy is less efficient in economies with high economic fluctuations or uncertainty and a larger share of domestic exports in GDP. Interestingly, we find that the shares of investment and the manufacturing sector to GDP, which are bank credit-sensitive variables, are statistically significant with negative signs, in contrast to their positive signs when we consider the impact of monetary policy. In summary, in relation to previous studies on monetary policy transmission in Indonesia, our findings corroborate the operation of the interest rate, bank lending and exchange rate channels of monetary policy transmission to regional inflation.

These different results for the overall monetary policy impact and monetary policy efficiency have important implications for evaluating monetary policy transmission at the regional level. The effect of monetary policy tends to materialize gradually over a longer time horizon in regions that have a higher share of interest-sensitive industries (manufacturing and mining industries) in their economy and a higher bank loan to GDP ratio, while the monetary policy effect is relatively fast and short-lived in regions that engage more in foreign import activities. Taken together, our results have implications for how the central bank can attain optimal monetary policy, in terms of both the size and time dimensions of monetary policy actions.

\section{Appendix}

See Tables 4, 5 
Table 4 List of variables used in PCA

\begin{tabular}{|c|c|c|c|c|}
\hline \multicolumn{2}{|c|}{$\begin{array}{l}\text { Factor: domestic financial system } \\
\text { condition } \\
\text { No. indicator }\end{array}$} & Definition & Units & \multirow[t]{2}{*}{ Original frequency } \\
\hline 1 & mo & $\begin{array}{l}\text { Currency outside commercial } \\
\text { and rural banks }\end{array}$ & IDR billion & \\
\hline 2 & $\mathrm{~m} 1$ & Narrow money & IDR billion & Monthly \\
\hline 3 & $\mathrm{~m} 2$ & Broad money & IDR billion & Monthly \\
\hline 4 & stock_vol & $\begin{array}{l}\text { Transaction volume at Jakarta } \\
\text { stock exchange }\end{array}$ & In million stocks & Monthly \\
\hline 5 & stock_val & $\begin{array}{l}\text { Transaction value at Jakarta } \\
\text { stock exchange }\end{array}$ & IDR billion & Monthly \\
\hline 6 & stock_indx & $\begin{array}{l}\text { Jakarta stock exchange compos- } \\
\text { ite index }\end{array}$ & & Monthly \\
\hline 7 & LQ45 & $\begin{array}{l}\text { Index of } 45 \text { stocks that meet a } \\
\text { number of specific criteria }\end{array}$ & & Monthly \\
\hline 8 & jibor_1d & $\begin{array}{l}\text { Jakarta interbank offered rate for } \\
\text { overnight }\end{array}$ & $\%$ & Monthly \\
\hline 9 & jibor_1m & $\begin{array}{l}\text { Jakarta interbank offered rate for } \\
1 \text { month }\end{array}$ & $\%$ & Monthly \\
\hline 10 & jibor_3m & $\begin{array}{l}\text { Jakarta interbank offered rate for } \\
3 \text { months }\end{array}$ & $\%$ & Monthly \\
\hline 11 & int_lend_inv & $\begin{array}{l}\text { Bank lending rate IDR for invest- } \\
\text { ment purposes }\end{array}$ & $\%$ & Monthly \\
\hline 12 & int_lend_wc & $\begin{array}{l}\text { Bank lending rate IDR for work- } \\
\text { ing capital purposes }\end{array}$ & $\%$ & Monthly \\
\hline 13 & int_lend_cons & $\begin{array}{l}\text { Bank lending rate IDR for con- } \\
\text { sumption purposes }\end{array}$ & $\%$ & Monthly \\
\hline 14 & int_sav_1m & $\begin{array}{l}\text { Bank time deposit (saving) rate } \\
\text { for } 1 \text { month }\end{array}$ & $\%$ & Monthly \\
\hline 15 & int_sav_3m & $\begin{array}{l}\text { Bank time deposit (saving) rate } \\
\text { for } 3 \text { months }\end{array}$ & $\%$ & Monthly \\
\hline 16 & int_sav_6m & $\begin{array}{l}\text { Bank time deposit (saving) rate } \\
\text { for } 6 \text { months }\end{array}$ & $\%$ & Monthly \\
\hline 17 & int_sav_12m & $\begin{array}{l}\text { Bank time deposit (saving) rate } \\
\text { for } 12 \text { months }\end{array}$ & $\%$ & Monthly \\
\hline \multicolumn{2}{|c|}{ 18int_sav_24m } & $\begin{array}{l}\text { Bank time deposit (saving) rate } \\
\text { for } 24 \text { months }\end{array}$ & $\%$ & Monthly \\
\hline \multicolumn{2}{|c|}{$\begin{array}{l}\text { Factor: global economic and } \\
\text { financial conditions } \\
\text { No. indicator }\end{array}$} & Definition & Units & Original frequency \\
\hline 1 & crude_oil_avg & $\begin{array}{l}\text { Commodity monthly price, } \\
\text { average }\end{array}$ & US\$/barrel & Monthly \\
\hline 2 & crude_oil_brent & $\begin{array}{l}\text { Commodity monthly price, } \\
\text { Brent }\end{array}$ & US\$/barrel & Monthly \\
\hline 3 & crude_oil_dubai & $\begin{array}{l}\text { Commodity monthly price, } \\
\text { Dubai }\end{array}$ & US\$/barrel & Monthly \\
\hline 4 & crude_oil_wti & Commodity monthly price, WTI & US\$/barrel & Monthly \\
\hline 5 & wcom_en & $\begin{array}{l}\text { Commodity monthly price } \\
\text { index, energy }\end{array}$ & $2010=100$ & Monthly \\
\hline 6 & wcom_nen & $\begin{array}{l}\text { Commodity monthly price } \\
\text { index, nonenergy }\end{array}$ & $2010=100$ & Monthly \\
\hline 7 & wcom_agri & $\begin{array}{l}\text { Commodity monthly price } \\
\text { index, agriculture }\end{array}$ & $2010=100$ & Monthly \\
\hline 8 & wcom_bvrg & $\begin{array}{l}\text { Commodity monthly price } \\
\text { index, beverage }\end{array}$ & $2010=100$ & Monthly \\
\hline 9 & wcom_food & $\begin{array}{l}\text { Commodity monthly price } \\
\text { index, foods }\end{array}$ & $2010=100$ & Monthly \\
\hline
\end{tabular}


Table 4 (continued)

\begin{tabular}{|c|c|c|c|c|}
\hline \multicolumn{2}{|c|}{$\begin{array}{l}\text { Factor: global economic and } \\
\text { financial conditions } \\
\text { No. indicator }\end{array}$} & \multirow{2}{*}{$\begin{array}{l}\text { Definition } \\
\begin{array}{l}\text { Commodity monthly price } \\
\text { index, oil and meals }\end{array}\end{array}$} & \multirow{2}{*}{$\begin{array}{l}\text { Units } \\
2010=100\end{array}$} & \multirow{2}{*}{$\begin{array}{l}\text { Original frequency } \\
\text { Monthly }\end{array}$} \\
\hline 10 & wcom_oilmeals & & & \\
\hline 11 & wcom_grains & $\begin{array}{l}\text { Commodity monthly price } \\
\text { index, grains }\end{array}$ & $2010=100$ & Monthly \\
\hline 12 & wcom_othrfood & $\begin{array}{l}\text { Commodity monthly price } \\
\text { index, other foods }\end{array}$ & $2010=100$ & Monthly \\
\hline 13 & wcom_rawmat & $\begin{array}{l}\text { Commodity monthly price } \\
\text { index, raw materials }\end{array}$ & $2010=100$ & Monthly \\
\hline 14 & wcom_timber & $\begin{array}{l}\text { Commodity monthly price } \\
\text { index, timber }\end{array}$ & $2010=100$ & Monthly \\
\hline 15 & wcom_otherrawmat & $\begin{array}{l}\text { Commodity monthly price } \\
\text { index, raw materials }\end{array}$ & $2010=100$ & Monthly \\
\hline 16 & wcom_fert & $\begin{array}{l}\text { Commodity monthly price } \\
\text { index, fertilizer }\end{array}$ & $2010=100$ & Monthly \\
\hline 17 & wcom_metal & $\begin{array}{l}\text { Commodity monthly price } \\
\text { index, metal }\end{array}$ & $2010=100$ & Monthly \\
\hline 18 & wcom_basemetal & $\begin{array}{l}\text { Commodity monthly price } \\
\text { index, base metal }\end{array}$ & $2010=100$ & Monthly \\
\hline 19 & prec_metal & $\begin{array}{l}\text { Commodity monthly price } \\
\text { index, precious metal }\end{array}$ & $2010=100$ & Monthly \\
\hline 20 & inds_US_sa & $\begin{array}{l}\text { US industrial production index, } \\
\text { seasonally adjusted }\end{array}$ & $2012=100$ & Monthly \\
\hline 21 & inds_CHN & $\begin{array}{l}\text { China industrial production } \\
\text { index (total industry excluding } \\
\text { construction), not SA }\end{array}$ & $2000=100$ & Monthly \\
\hline 22 & cpi_US_sa & $\begin{array}{l}\text { US consumer price index, sea- } \\
\text { sonally adjusted }\end{array}$ & $1982=100$ & Monthly \\
\hline 23 & cpi_CHN & $\begin{array}{l}\text { China consumer price index, not } \\
\text { seasonally adjusted }\end{array}$ & $2015=100$ & Monthly \\
\hline 24 & ppi_US & $\begin{array}{l}\text { US producer price index, not } \\
\text { seasonally adjusted }\end{array}$ & $1982=100$ & Monthly \\
\hline
\end{tabular}

Table 5 Contemporaneous coefficients estimated from structural FAVAR model

\begin{tabular}{llllll}
\hline Variable & GDPg & INF & POL & NER & FIN \\
\hline GDPg $(-1)$ & 0.88 & 0.08 .58 & 0.04 & $-8 \mathrm{E}-04$ & 0.07 \\
& $(0.04)$ & $(12.28)$ & $(3.65)$ & $(0.33)$ & $(28.50)$ \\
INF $(-1)$ & $5 \mathrm{E}-03$ & 0.90 & 0.03 & $2 \mathrm{E}-03$ & 0.37 \\
& $(0.00)$ & $(0.05)$ & $(0.02)$ & $(0.00)$ & $(0.12)$ \\
POL $(-1)$ & $-7 \mathrm{E}-03$ & -0.01 & 0.92 & $-3 \mathrm{E}-03$ & -0.31 \\
& $(0.00)$ & $(0.08)$ & $(0.02)$ & $(0.00)$ & $(0.18)$ \\
NER $(-1)$ & 0.27 & 5.25 & 1.30 & 0.20 & 7.46 \\
& $(0.01)$ & $(3.61)$ & $(1.07)$ & $(0.10)$ & $(8.38)$ \\
FIN $(-1)$ & $-8 \mathrm{E}-03$ & 0.03 & 0.03 & $2 \mathrm{E}-04$ & 0.63 \\
& $(0.00)$ & $(0.03)$ & $(0.01)$ & $(0.00)$ & $(0.07)$ \\
C & 0.62 & 0.05 & 0.10 & 0.01 & -0.21 \\
& $(0.00)$ & $(0.76)$ & $(0.23)$ & $(0.02)$ & $(1.77)$ \\
EXT & $-9 \mathrm{E}-03$ & -0.03 & -0.01 & $-1 \mathrm{E}-03$ & -0.01 \\
& $(0.00)$ & $(0.02)$ & $(0.01)$ & $(0.00)$ & $(0.05)$ \\
R-squared & 0.82 & 0.89 & 0.98 & 0.13 & 0.61 \\
Adj. $R$-squared & 0.81 & 0.89 & 0.97 & 0.08 & 0.59 \\
\hline
\end{tabular}

Standard errors in (). Source: Authors' calculation 


\section{Acknowledgements}

The authors would like to appreciate all participants of the 5th International Conference on Economic Structures (ICES 2021) for their constructive comments and suggestions to improve this paper.

\section{Authors' contributions}

HA collected data, developed theoretical framework, designed and performed computation, analyzed the data, interpreted the results, and wrote the manuscript. MS supervised the research, performed computation, interpreted the results, and co-wrote the manuscript. Both the authors discussed the results and commented on the manuscript. Both the authors read and approved the final manuscript.

\section{Funding}

The authors declare that they received no specific funding for this work.

\section{Availability of data and materials}

Data and materials used in this study are available and stored in digital repositories https://figshare.com/s/6d9b852fec $754 \mathrm{c} 7796 \mathrm{ba}$

\section{Declarations}

Ethics approval and consent to participate

Not applicable.

\section{Consent for publication}

Not applicable.

\section{Competing interests}

No potential competing interests was reported by the authors.

\section{Author details}

${ }^{1}$ Bank Indonesia and Graduate School of International Development, Nagoya University, Nagoya, Japan. ${ }^{2}$ Graduate School of International Development, Nagoya University, Nagoya, Japan.

Received: 27 April 2021 Revised: 8 December 2021 Accepted: 23 December 2021

Published online: 06 January 2022

\section{References}

Affandi Y et al (2011) Unveiling stubborn inflation in Indonesia. Ekon Keuang Indones 59(1):47

Aginta $\mathrm{H}$ (2020a) Does the law of one price hold in 82 Indonesian cities? Evidence from club convergence approach. Econ Bull 40(4):2844-2858

Aginta $\mathrm{H}$ (2020b) Spatial dynamics of consumer price in Indonesia: convergence clubs and conditioning factors. Asia Pac J Reg Sci. https://doi.org/10.1007/s41685-020-00178-0

Alamsyah H, Joseph C, Agung J, Zulverdy D (2001) Towards implementation of inflation targeting in Indonesia. Bull Indones Econ Stud 37(3):309-324

Anagnostou A, Papadamou S (2016) Regional asymmetries in monetary policy transmission: the case of the Greek regions. Eviron Plann C Gov Policy 34(5):795-815

Arnold IJ, Vrugt EB (2002) Regional effects of monetary policy in the Netherlands. Int J Bus Econ 1(2):123

Arnold IJ, Vrugt EB (2004) Firm size, industry mix and the regional transmission of monetary policy in Germany. Ger Econ $\operatorname{Rev} 5(1): 35-59$

Bagliano FC, Morana C (2009) International macroeconomic dynamics: a factor vector autoregressive approach. Econ Model 26(2):432-444

Ber H, Blass A, Yosha O et al (2001) Monetary transmission in an open economy: the differential impact on exporting and non-exporting firms. Bank of Israel, Research Department, Israel

Bernanke BS, Blinder AS (1992) The federal funds rate and the channels of monetary transmission. Am Econ Rev 82(4):901-921

Bernanke BS, Boivin J (2003) Monetary policy in a data-rich environment. J Monet Econ 50(3):525-546

Bernanke BS, Boivin J, Eliasz P (2005) Measuring the effects of monetary policy: a factor-augmented vector autoregressive (FAVAR) approach. Q J Econ 120(1):387-422

Boivin J, Kiley MT, Mishkin FS (2010) How has the monetary transmission mechanism evolved over time? Handbook of Monetary Economics, vol 3. Elsevier, Amsterdam, pp 369-422

Carlino G, DeFina R (1998) The differential regional effects of monetary policy. Rev Econ Stat 80(4):572-587

Carlino G, DeFina R (1999) The differential regional effects of monetary policy: evidence from the US states. J Reg Sci 39(2):339-358

Cecchetti SG et al (1999) Legal structure, financial structure, and the monetary policy transmission mechanism. Econ Policy Rev 5:9-28

Cecchetti SG, Mark NC, Sonora RJ (2002) Price index convergence among United States cities. Int Econ Rev 43(4):1081-1099

Christiano LJ, Eichenbaum M, Evans CL (1999) Monetary policy shocks: what have we learned and to what end? Handb Macroecon 1:65-148 
Christoffel K, Kuester K (2008) Resuscitating the wage channel in models with unemployment fluctuations. J Monet Econ 55(5):865-887

De Grauwe P (2000) Monetary policies in the presence of asymmetries. J Common Mark Stud 38(4):593-612

Del Negro M, Schorfheide F, Smets F, Wouters R (2007) On the fit of New Keynesian models. J Bus Econ Stat 25(2):123-143 Dominguez-Torres H, Hierro LA (2019) The regional effects of monetary policy: a survey of the empirical literature. J Econ Surv 33(2):604-638

Dornbusch R, Favero C, Giavazzi F (1998) Immediate challenges for the European central bank. Econ Policy 13(26):16-64 Fuhrer J, Moore G (1995) Inflation persistence. Q J Econ 110(1):127-159

Galí J (2015) Monetary policy, inflation, and the business cycle: an introduction to the New Keynesian framework and its applications; second edition. Technical report. Princeton University Press, Princeton

Garrison CB, Chang HS (1979) The effect of monetary and fiscal policies on regional business cycles. Int Reg Sci Rev 4(2):167-180

Garrison CB, Kort JR (1983) Regional impact of monetary and fiscal policy: a comment. J Reg Sci 23(2):249-261

Gros D, Hefeker C (2002) One size must fit all: national divergences in a monetary union. Ger Econ Rev 3(3):247-262

Harahap BA, Maryaningsih N, Nurliana LP, Satyanugroho R (2013) Revisiting transmisi suku bunga kebijakan moneter: pendekatan FAVAR. Technical report, working paper. Bank Indonesia, Indonesia

Hayo B, Uhlenbrock B (2000) Industry effects of monetary policy in Germany. Regional aspects of monetary policy in Europe. Springer, Berlin, pp 127-158

Hill H, Resosudarmo BP, Vidyattama Y (2008) Indonesia's changing economic geography. Bull Indones Econ Stud 44(3):407-435

Jangam BP, Akram V (2019) Do prices converge among Indonesian cities? An empirical analysis. Bul Ekon Monet Perbank 22(3):239-262

Kusmiarso B, Sukawati E, Pambudi S, Angkoro D, Prasmuko A, Hafidz IS (2002) Interest rate channel of monetary transmission in Indonesia. Transmission Mechanism of Monetary Policy in Indonesia. Strategic Research Program of the Directorate of Economic Research and Monetary Policy, Directorate of Economic Research and Monetary Policy, Bank Indonesia, Indonesia

Laine O-MJ (2019) The effect of the ecbâs conventional monetary policy on the real economy: FAVAR-approach. Empir Econ. https://doi.org/10.1007/s00181-019-01739-9

Lechthaler W, Merkl C, Snower DJ (2010) Monetary persistence and the labor market: a new perspective. J Econ Dyn Control 34(5):968-983

Mankiw NG (2001) The inexorable and mysterious tradeoff between inflation and unemployment. Econ J 111(471):45-61

Mihov I (2001) Monetary policy implementation and transmission in the European monetary union. Econ Policy 16(33):370-406

Mishkin FS (1996) The channels of monetary transmission: Lessons for monetary policy. Technical report. National Bureau of Economic Research, Cambridge

Nurliana L, Wimanda RE, Satyanugraha R, SEACEN Centre (2016) Evaluating monetary transmission mechanism in Indonesia using a structural FAVAR approach. Monetary policy transmission in the SEACEN economies. The SEACEN Centre, Kuala Lumpur, pp 19-56

Purwono R, Yasin MZ, Mubin MK (2020) Explaining regional inflation programmes in Indonesia: does inflation rate converge? Econ Chang Restruct. https://doi.org/10.1007/s10644-021-09343-7

Ramey VA (2016) Macroeconomic shocks and their propagation. Handb Macroecon 2:71-162

Resosudarmo BP, Vidyattama Y (2006) Regional income disparity in Indonesia: a panel data analysis. ASEAN Econ Bull. 23(1):31-44. https://doi.org/10.1355/AE23-1C

Ridhwan MM, de Groot HL, Rietveld P, Nijkamp P (2014) The regional impact of monetary policy in Indonesia. Growth Chang 45(2):240-262

Taylor JB (1995) The monetary transmission mechanism: an empirical framework. J Econ Perspect 9(4):11-26

Tirtosuharto D, Adiwilaga H (2013) Decentralization and regional inflation in Indonesia. Bul Ekon Monet Perbank 16(2):137-154

Toal WD (1977) Regional impacts of monetary and fiscal policies in the postwar period: some initial tests. Federal Reserve Bank of Atlanta, Atlanta

Wimanda RE, Turner PM, Hall MJ (2011) Expectations and the inertia of inflation: the case of Indonesia. J Policy Model 33(3):426-438

Yesilyurt F, Elhorst JP (2014) A regional analysis of inflation dynamics in Turkey. Ann Reg Sci 52(1):1-17

Zanetti F (2007) A non-Walrasian labor market in a monetary model of the business cycle. J Econ Dyn Control 31(7):2413-2437

\section{Publisher's Note}

Springer Nature remains neutral with regard to jurisdictional claims in published maps and institutional affiliations. 